\title{
Aceh Women's Contribution of Military Affairs During Western Colonialism in Indonesia
}

\author{
$1^{\text {st }}$ Yuliati ${ }^{*}$ \\ Dep. of History, Faculty of Social Science, \\ Universitas Negeri Malang, Malang, Indonesia \\ yuliati.fis@um.ac.id \\ $2^{\text {nd }}$ Moch. Nurfahrul Lukmanul Khakim \\ Dep. of History, Faculty of Social Science, \\ Universitas Negeri Malang, Malang, Indonesia
}

Abstract-Aceh has a great history of faces and against colonialism in Indonesia, include women's contributions. The women's history clearly shows women's involvement in politics and military affairs. It is also supported by achievements of a number of tough women who entitled to heroes, such as Cut Nyak Dien, Cut Meutia, and Laksamana Keumalahayati. In the historical record, Aceh is well known to have a strong Moslem principle that roots deeply in the vein of its people. It gave impact to the function of religious leaders in progressive government which positions women in important stances. Contribution of the struggle in Acehnese women's behavior and contributions is quite

\section{INTRODUCTION}

Aceh is located in Sumatera Island. Aceh has a long history line that is not quite well known by common Indonesian people. One of the most memorable history for Aceh people is the emersion of female patriots. For example, Laksamana Keumalahayati, Cut Nyak Din, Cut Meutia, and many others. There were many female patriots coming from Aceh, and their role is quite important in the history of women. A large number of female patriots in the colonization era becomes a great interest for deeper research. This research's purpose is to reveal why women in Aceh have important positions, also the reason why Aceh is different from any other region.

The struggle of Acehnese women during the Dutch occupation in Indonesia was

\author{
$3^{\text {rd Afifah Rahmantika Furzaen }}$ \\ Dep. of History, Faculty of Social Science, \\ Universitas Negeri Malang, Malang, Indonesia
}

$4^{\text {th }}$ Ezra Imanuel Suwarno

Dep. of History, Faculty of Social Science, Universitas Negeri Malang, Malang, Indonesia

interesting to be thoroughly analyzed through literature study and historical research. In another place in Indonesia like Java Island, most women of contribution are in education and politics. The characteristic of women involvement in the government was political activity and military affair, as a queen and an admiral. The purpose of this research is to reveal the contribution and the manifestation of women's exist in the past time. Women involvement in public affairs oppose the myth that political and military affairs are dominated by male

Keywords-Aceh Women, Contribution, Western Colonialism

different from the struggle of women in other regions of Indonesia. For example in Java, Kartini struggled to promote the welfare of indigenous people through education, culture, and arts such as carving [1]. Based on historical sources and folklore, during the Dutch colonial era the majority of Acehnese women's struggles in the military field. Another purpose of this research is to adopt the values of woman's virtue in Acehnese culture through observing its history.

The struggle in Acehnese women's behavior and attitude is quite interesting to be analyzed because Acehnese women are always sure to risk their souls in maintaining what they see as a matter of nationality and religion. Literally, the Islamic principle is the most important value for Acehnese.This is also could be the reason why Aceh was so strong in 
the era of Moslem Kingdoms. This case continued to the colonization era when Aceh was colonized. Aceh's condition in that time provoked various roles to occur, one of them was the role of women in Aceh.This study of the history of Acehnese women is important for the development of historical material or information. Historical material that is relevant to important facts to build historical awareness in society [2].

\section{METHOD}

The method of this research is a literature study. Literature research method or also named literature study is a way of activities related to data collection methods, reading, reviewing and recording and analyzing research materials [3]. This research method is in accordance with the preparation of this article because it uses books, journals and articles relating to Aceh Women's Contribution to against western colonialism in Indonesia. The researcher reads all the literature on the history of Acehnese women and then notes and summarizes the important things. The results of the summary were analyzed by historical methods.

This literature study method is complemented by the historical method because the focus of this study is on the contribution of Acehnese women in the fight against Dutch colonialism in the archipelago. This historical method is appropriate for use in research because it can uphold interpretation and analysis in historiography. The historical method is a way or step in rebuilding past events, through four stages of research, namely heuristics, source criticism, interpretation, and historiography [4]. Heuristics or collecting reference sources on the history of women's struggle in Aceh. A literature study consists of 10 books and 15 journals. It is complemented by a critique of the accuracy of relevant reference sources. Interpretation from each source to be able to reconstruct the role of Acehnese women in fighting Dutch colonialism. Historiography is writing the results of reconstruction chronologically and scientifically.

\section{RESULTS AND DISCUSSION}

\section{Aceh Condition in the Colonization Era}

The province of Nangroe Aceh Darussalam is located in the far west of Indonesia, which is very advantageous. It is spread from northwest to southeast, between Strait of Malacca and Indian Ocean (Biro Pusat Statistik dan Sensus Propinsi Daerah Istimewa Aceh 1998). Thus, Aceh is an advantageous place geographically. This advantage makes Aceh people a maritime society that was used to nautical life and pleasant to foreigners. Aceh's First Islamic Kingdom, Samudera, has a strategic port that was used for 150 years. The current port called Lhosumawe is located in the easternmost corner of the island of Sumatra east of the Muslim trade route, from a leading center of knowledge and trade[5]. This virtue was held until the influence of Moslem reached Aceh.

The moslem influence was proved to be very strong, that people call Aceh as 'Serambi Mekkah', literally means the Foyer of Mecca. Because Islam had a very strong influence of immigrant virtues and cultures which was brought in by Arabic people around the $12^{\text {th }}$ century. The Sultanate of Aceh once was the biggest Sultanate in Southeast Asia under the governance of Ali Muchayat Shah [6].

The Sultanate of Aceh was also related to the role of women, and Aceh women could make it into the history of Aceh. It is shown by a large number of women who were standing out in terms of leadership and insurgent. Long before The Sultanate of Aceh was established, Aceh was led by a woman named Puteri Lindung Bulan of The Sultanate of Benua or Teaming (1333-1398) and Queen Nihrasiyah Rawangsa Khadiyu of Samudra Pasai Sultanate[17].

The role of women in Aceh continued until the colonization era. During that time, many of them existed as a leader of the revolutionary and independence movement. Some of them were Pocut Meulingo, Tengku Fakinah, Cut Nyak Dien, Cut Meutia, dan Pocut Baren Blue. 


\section{The Emerging of Female Patriots in Aceh}

Most of the research or academic works in terms of nationalism often times are quite unfair in discussing history from the perspective of gender. Gender relation, which plays a major role in the fighting of gaining power, is frequently put aside [7]. Therefore, nationalism is distortedly presented by most researchers as something that comes from 'masculinized memory, masculinized humi liation, and masculinized hope'[8]. According to [9] 'male theorists are typically indifferent to the gendering of nations'.

Observing the role of female patriots in Aceh in its struggle, apparently, they were consequently influenced by cultures, locations in the coast, traditions, and laws that went through Arabic cultures and Moslem religion. It is shown by the record in the $7^{\text {th }}$ century, when hundreds of women went to Madinah because Muhammad SAW and his followers promised equality and honor for everyone, both men and women, also masters and servants. Every woman who came to Madinah when the Prophet was in charge of politics, might fully gain the advantages of a citizen and were given a title as sahabi or the Prophet's friend. They are called sahabiyat and able to join the Moslem Umma Council. They have the freedom to communicate with The Prophet, spar with men, fight for their happiness, and being involved in the politics and military affairs.

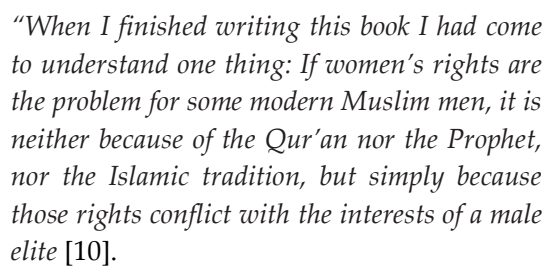

"When I finished writing this book I had come to understand one thing: If women's rights are the problem for some modern Muslim men, it is neither because of the Qur'an nor the Prophet, nor the Islamic tradition, but simply because those rights conflict with the interests of a male elite [10].

Shari'a, Al-Quran, and Moslem tradition are not transcendental nor beyond humans. Even though these studies acknowledge that there is a sexual hierarchy in Islam, there are also arguments to shift power it in Moslem ethics [11]. Apparently, nationalism construction in Aceh is clearly related to gender. In relation to the discussion above, the next question is how women in Aceh could manage to be commanders in the war, eventually being honored as patriots. It will need a special discussion also regarding many views such as gender, cultures, and religion to answer it; how they could lead Aceh even when they were underestimated. Not only the heroic struggle of Aceh women, but we should also examine the background of their struggle; which makes them decide to stand out in the fight.

Aceh War was a manifestation of people's resistance toward Dutch Colony, which was considered as the hardest and the longest fight for Dutch Colony itself. The persistence of Aceh people to defend their land was very strong, which made it difficult to occupy. During Aceh War, there was a female patriot who played an important role and made Dutch Colony pay a great effort and expense to stop her; her name was Cut Nyak Dien. Thus, Indonesia Government grants her a title as a National Independence Hero of Indonesia by Presidential Decree No. 106/1964 dated May 2nd, 1964 [12].

Cut Nyak Dien is a tough woman during Aceh War. Although she was very busy participating in the movement, she did not neglect her duty as a wife to her spouse. There was a time when her husband, Teuku Umar sided with the Colony, but she reminded her husband to keep his loyalty to Indonesia. Cut Nyak Dien influenced her husband immensely. She was the one who persuaded Teuku Umar to rebel against Dutch in 1896 [13]. Without Cut Nyak Dien's support, Teuku Umar would find difficulties way to extend his fight.

Dutch Colony considered Cut Nyak Dien as a fanatics because she did not give up on Dutch, not even once. [14]assumed that after the death of Teuku Umar, Cut Nyak Dien continued her fight in West Coast Aceh. [15]added that Cut Nyak Dien was the most wanted person among the Colony (1899-1905) because she presented herself as the successor of her husband's fight. It is also interesting that although she was in her middle age when her husband died, this middle-aged woman boldly took control and led the guerrilla movement in West Aceh. Through those changes, Cut Nyak Dien became a master of 
guerilla strategy and overwhelmed Dutch Colony.

Firmness, courage, strong in spirit, and agility are courtesy demonstrated by Cut Nyak Dien for Indonesian women to adopt. She was an honorable woman, loyal to her husband, country, and her faith. Those qualities make her great. She was highly regarded among Aceh Leaders, even Dutch Colony acknowledged her. Dutch Colony delivers its admiration toward Cut Nyak Dien's agility and spirit during her fight ${ }^{15}$. Almost all Dutch Leader, such as Van Heutsz, Van Daalen, Van der Maaten, Veltman, H. Colijn, Christoffel, up to common officers, had tried to defeat her, but none of them succeeded. Then, one day she was captured and exiled to outside Aceh, although once again she became the object of admiration in the new place.

Dutch had never experienced a bigger battle than the Aceh War [13]. It was the hardest and the longest battle in occupying Indonesia. The Colony had to lose commanders, excellent soldiers, and a big amount of money. Occupying Aceh became overwhelming as there was much rebellion that arose all around Aceh at the same time, and their blazing spirit made it hard to occupy them in a short time. North Aceh was one of the regions which rebelled against The Colony; Cut Meutia was a dominant leader over there that interested Dutch Colony the most.

Cut Meutia was another female patriot who rebelled against The Colony all along with her life. Cut Meutia has a very strong jihad spirit which is run in her blood. Jihad comes from the phrase "jahada jahdan" whose meaning is the mobilization of all abilities which when experiencing difficulties. If "jahada jihadan" is an effort to protect or defend Islam or the state so that the designation of al-mujahadah is an effort to fight the enemy including fighting against infidelity, ignorance, illness, and others [16]. Cut Meutia's ancestor from his father's line (Teuku Ben Daud) who lived around 400 years before her, was a religious nobleman closely related to Darud Dunia Sultanate in Banda Aceh. His name was Tok
Bineh Blang [17].Cut Meutia grew in the time of the Aceh War, so her parents taught her to defend her faith and especially her nation. Her father was always cooperated with the Sultanate and against Dutch Colony. Therefore, her father's spirit was indirectly imparted to her and her children from early age.

In Aceh especially Keureunto region, Cut Meutia always played a big role in the frontline. Similar to Cut Nyak Dien, Cut Meutia was a faithful wife; she accompanied her husband in the warzone. Being a woman did not stop her to stand on the frontline against Dutch. In addition to that, her intelligence helped her to master defending and attacking strategy that cost Dutch great amount of money. [18] said Dutch officers acknowledged that their 10 years effort became useless because of Cut Meutia (Het werk van tien jaren vechten scheen voor ons volkomen en het moeten prettige dagen zijn geweest voor Tjoet Meutia, die heel Keureuto in deining en onrust zag /The work of ten years of fighting seemed perfect for us and must have been pleasant days for Tjoet Meutia, who saw Keureuto in swell and unrest).

Loss and damage caused by guerilla movement led and arranged by Cut Meutia along with her husband urged Dutch to make a special force called Kolone Macan to defeat Cut Meutia and her people. However, this special force could not defeat her speed and strategy, thus failed many times. The great impact of Cut Meutia among Aceh people amazed also irritated the Dutch Colony. Zentgraaff said everywhere, including Lho' Sukon, Keureuto, and other parts of Aceh, partisans are bustling. Villages were empty, rice fields were abandoned, hundreds of people gathered on the mountain. It was the condition when Keureuto, Lho' Sukon, Pase, and other villages got together in a rebellion. Those days were the victorious days of Cut Meutia [19].

After years of fight, eventually, Dutch managed to ambush Cut Meutia directly. In 1910, Cut Meutia died on war as a commander; she got an honored title from Queen Wilhemina. After Cut Meutia passed 
away, her spirit gave impact immensely and encouraged fellow partisans, especially women, to fighting for freedom. Cut Meutia was honored for her noble deed as a National Independence Hero by Presidential Decree No. 107/TK/1973 dated November $6^{\text {th }}, 1971$ ecause of her contributions[12].

Besides two great names mentioned above, apparently Aceh had a long history with female leadership. Aceh identity was indeed absolute even though Aceh culture and perspective that might degrade female in general. Anyone could be the leader to cast out cruelty from their land. It is also supported by Prof. A. Hajsmy[20]:

"... in the past, Aceh Sultanate treated men and women equally. Women's right

\begin{abstract}
to lead was acknowledged ultimately. According to Aceh Sultanate, both genders had the same right. So did their duty to contribute in developing and defending the Sultanate .... The said right and duty provided opportunities for Aceh women from The Sultanate of Perlak, Samudera Pasai, and Aceh Darussalam to be acively involved in administration and military affair."
\end{abstract}

The record shows that Aceh women might use the politic condition to hold onto their power for a long time. Aceh women held the highest power as a queen since the beginning of the $15^{\text {th }}$ century until the end of the $17^{\text {th }}$ century. The following table shows great positions that were held by women in Aceh.

Table 1. List of Aceh Women who had the Responsibility of Making the Decision Before and After the Fight Against Dutch Colony in 1873

\begin{tabular}{|c|c|c|c|}
\hline Name & Position & Time & Place \\
\hline Putri Lindung Bulan & Prime Minister & $1353-1398$ & Perlak Sultanate \\
\hline Nihrasiyah Rawangsa & Queen & $1400-1428$ & Samudera Pasai \\
\hline Khadiyu & & & Sultanate \\
\hline Malahayati & Admiral & $1589-1604$ & $\begin{array}{l}\text { The Sultanate of Aceh } \\
\text { Darussalam }\end{array}$ \\
\hline Meurah Ganti & Admiral & $1604-1607$ & $\begin{array}{l}\text { The Sultanate of Aceh } \\
\text { Darussalam }\end{array}$ \\
\hline Cut Meurah Inseuen & Rear admiral & $1604-1607$ & $\begin{array}{l}\text { The Sultanate of Aceh } \\
\text { Darussalam }\end{array}$ \\
\hline Taj' Al Alam & Queen & $1641-1675$ & $\begin{array}{l}\text { The Sultanate of Aceh } \\
\text { Darussalam }\end{array}$ \\
\hline Cut Nyak Keureuto & $\begin{array}{l}\text { Kepala Daerah Otonom / } \\
\text { Uleebalang }\end{array}$ & $1641-1675$ & $\begin{array}{l}\text { The Sultanate of Aceh } \\
\text { Darussalam }\end{array}$ \\
\hline Cut Nyak Fatimah & $\begin{array}{l}\text { Head of Autonomous } \\
\text { Region / Uleebalang }\end{array}$ & $1641-1675$ & $\begin{array}{l}\text { The Sultanate of Aceh } \\
\text { Darussalam }\end{array}$ \\
\hline $\begin{array}{l}\text { Seri Ratu Nurul Alam } \\
\text { Nakiatu'ddin Sjah }\end{array}$ & Queen & $1675-1678$ & $\begin{array}{l}\text { The Sultanate of Aceh } \\
\text { Darussalam }\end{array}$ \\
\hline $\begin{array}{l}\text { Sultan Inayat } \\
\text { Zakiatuddin Sjah }\end{array}$ & Queen & $1678-1688$ & $\begin{array}{l}\text { The Sultanate of Aceh } \\
\text { Darussalam }\end{array}$ \\
\hline Seri Ratu Kamalat Syah & Queen & $1688-1699$ & $\begin{array}{l}\text { The Sultanate of Aceh } \\
\text { Darussalam }\end{array}$ \\
\hline Pocut Meulingo & $\begin{array}{l}\text { Uleebalang, War } \\
\text { consultant, and General in } \\
\text { Samalanga }\end{array}$ & $\begin{array}{l}\text { The end of } 18^{\text {th }} \\
\text { century (1857) }\end{array}$ & $\begin{array}{l}\text { During the fight } \\
\text { against Dutch Colony }\end{array}$ \\
\hline Tengku Fakinah & $\begin{array}{l}\text { Generals and cleric, have } \\
\text { a dayah(center of islam } \\
\text { education) }\end{array}$ & $1856-1933$ & $\begin{array}{l}\text { During the fight } \\
\text { against Dutch Colony } \\
\text { Belanda }\end{array}$ \\
\hline Cut Nyak Dien & General in West Aceh & $\begin{array}{l}\text { Died on } 8^{\text {th }} \\
\text { November } 1908\end{array}$ & $\begin{array}{l}\text { During the fight } \\
\text { against Dutch Colony }\end{array}$ \\
\hline
\end{tabular}


in exile

\begin{tabular}{|c|c|c|c|}
\hline Cut Meutia & General in North Aceh & $\begin{array}{l}\text { Died on } 25^{\text {th }} \\
\text { Oktober } 1910\end{array}$ & $\begin{array}{l}\text { During the fight } \\
\text { against Dutch Colony }\end{array}$ \\
\hline Pocut Baren Biheue & General in West Aceh & $\begin{array}{l}\text { Early } 19^{\text {th }} \\
\text { century }\end{array}$ & $\begin{array}{l}\text { During the fight } \\
\text { against Dutch Colony }\end{array}$ \\
\hline
\end{tabular}

The fact shows that prior to the end of the $19^{\text {th }}$ century, Aceh women played a great role in decision making (as a queen, prime minister, and autonomic governor called ullebalang) and during the war against Dutch Colony (as a commander, general, and soldier). The war actually start between Aceh and Portuguese in $16^{\text {th }}$ century and then against Dutch. Table 1 shows data from a historical study about Aceh woman's role in decision making in the past. The table shows that a large number of a woman held the position of decision making, which makes their active participation in politics was not an accident or a political manipulation by governors. Another historical record demonstrates that [21]:

\footnotetext{
"Dutch officers spoke to Aceh women in high regard and awe for their courage. Bravely Aceh women not afraid to put their life on the line for the sake of nationalism and faith. Aceh Women is directly involved in the 80-year war against Aceh and Dutch. In their awe, Aceh women were called as "de grootesDames" literally means mighty women who played a big role in Aceh politic war."
}

At the same page, Jakobi also wrote an excerpt from H.M Said in 'Aceh Sepanjang Abad' that as Van der Heijden attacked Samalanga, there was a woman named Pocut Meuligo, who persuaded her brother named Teuku Chik Samalanga to keep the rebellion movement against Dutch, so did Cut Nyak Dien to the husband, Teuku Umar. This record shows that it really happened at that time. If we do deeper research, we would find that many Aceh women having strong determination, such as Cut Meutiah who was found dead under the body of Pang Nanggroe [21].

\section{The Manifestation of Aceh Women Existence}

Nowadays, the contribution of Aceh women is unpopular to most Indonesian cause the curriculum of history in school did not explain about it. In Indonesian, their Aceh women are like 'mutiara berbalut taring singa', literally, means a pearl protected in lion's fang. They are delicate like pretty tropical pearls covered in the spiked case which not only allures men but also defeats soldiers on the warzone. That means their strength behind their delicate looks is not to be questioned. Female patriots such as Laksamana Keumalahayati, Cut Nyak Din, Cut Nyak Meutia surely are well-known. However, another interesting matter apart from history is the condition of Aceh women beyond the circle of nobility and religious leaders: whether they follow the model given by great women in the past, or satisfied enough being a housewife not knowing the struggle on their land [22].

It turned out that women beyond nobility also fight as men did. However, the case might be slightly different although it did not reduce patriotism spirit in them. Zentgraaf said that [22]:

"Even in defending an ideology for the sake of nationalism or faith, women had been led to an amazing fight, not less than men, both behind the scenes and in the frontline.

She moved forward with a greater emotional outburst compared to women of other countries, by that spirit they unsheathe swords on the battlefield. They were not afraid to follow their husband to the battlefield or inside the jungle, knowing all the danger and risk of being seized by the hiding Marsose spies.

They patted affectionately the baby inside her womb under the rain and so she delivered the baby. Sometimes delivering during the chaotic war time was common among them. Then, right after delivering babies, they moved along with the troops. Kelewang and rencong swept enemies in front of them, besides them, even in their delicate hands. Aceh women who fought based on 'sabilu'llah' (God's way) refuse to compromise; they would not betray their identity and only remembered one thing all along: kill or be killed!" 
Zentgraaf's statement shows that Aceh women beyond nobility or religious leader also experienced the tense of war, especially in relation to her children and her own safety. Their life during the war was not easy, even some of them gave birth in the midst of a chaotic and dangerous war condition. Being brave and courageous, Aceh women should be appreciated. They did not afraid of defending herself and her family although they had to use weapons.

We should highly regard the courage of Aceh women, which are usually called as 'para srikandi Aceh'. They put their life on the line for husband, faith, and nation. Among them, there were Pidie people who were well known as fanatics. When a partisan was shot to death, his wife brought him to her lap. Right after he was dead, she took her husband's kelewang (a traditional blade, used as a weapon) and continued the fight in her husband's place [22].

The chronicle of Aceh women's bravery and their heroic story actually are closely associated with a repressed situation that forced them to take sword and fight. However, as various cultures reached Aceh people year by year, their mindset was shifted. Regardless of all the proof and history facts, there were no women mentioned in Hikayat Perang Sabil. This phenomenon indicated that during the process of making Hikayat Perang Sabil, women's right to administration and politics affair was not acknowledged anymore.

Knowing the situation that women's role was fading on the battlefield, Aceh women did not give up. The oral tradition became a battlefield between those who wanted to remove women and those who wanted to get them involved. It is also a battlefield between those who marginalized women and those who empowered them. Interview with a number of female activists from Aceh reveals that nowadays Aceh women use oral tradition in the family to deliver information, value, and virtue toward their descendants. Their children would receive in detail the history of
Aceh and its heroes, both female and male through stories, poems, and songs. Their children as the student did not get that history details at school or from textbooks. Through the content, actually there is a conflict between Aceh nationalists turning women into a symbol of Islam and female activists fighting for equal rights supported by human right.

This is an excerpt from a song that was usually sung by Aceh women in the time of war as they fondled a baby in their bosom: Do kudaidang Lihatlah layang-layang yang terbang lepas. Cepat besar sayangku. Untuk membantu perang demi membela negerimu. Do Kudaidang cepat besar sayangku, mari berjihad untuk membela agama kita (Look at the flying kite. Grow quick, my darling. To help fight for your country. Grow quick, my darling. Lets fighting to protect our religion [23]. At first, oral tradition was delivered to sons and grandsons only, but then daughters and granddaughters got the chance to hear it. As time goes by, the song became like this: "Sayangku bibit selada di cermin Cepat besar anak perempuanku Gantikan ayahmu untuk melawan Belanda (My darling, lettuce seeds in the mirror, my daughter's fast, replace your father to fight the Dutch)." This song shows that it was an effort to erode gender bias in Aceh.

Therefore, although Aceh women were not mentioned on the script of Hikayat Perang Sabil in the $19^{\text {th }}$ century, and perhaps on any other Islamic script of the rise of religious leaders as a politician, they keep their decision making record alive through oral tradition. Their strategy to spread rebellion and selfaffirmation is subversive toward power relations which stand on Islamic interpretation that promotes gender inequality. This fight was a process of syllogism against dominant interpretation. It was about women who actively fought against gendered discrimination by subverting representations of gender and of re-creating new representations of gender, of womanhood, of identity and the collective self [24]. 


\section{CONCLUSIONS}

During the Dutch colonial era in Indonesia the most of Acehnese women's struggles in the military field. Before 12 Century, Before The Sultanate of Aceh was established, Aceh was led by a woman named Puteri Lindung Bulan of The Sultanate of Benua or Teaming (13331398) and Queen Nihrasiyah Rawangsa Khadiyu of Samudra Pasai Sultanate. After 12 Century, the Sultanate of Aceh was related to the role of women. It is shown by a large number of women who were standing out in terms of leadership and insurgent. The historical data shows that prior to the end of the $19^{\text {th }}$ century, Aceh women have a great role in decision making (as a queen, prime minister, and autonomic governor called ullebalang). They also fight for their homeland and justice during the war against Dutch Colony (as a commander, general, and soldier). The war actually starts between Aceh and Portuguese in the $16^{\text {th }}$ century and then against Dutch. Between 12-19 AD, all Aceh important women numbered 17 figures but the famous female heroes of Aceh are Laksamana Keumalahayati, Cut Nyak Din, Cut Nyak Meutia. The chronicle of Aceh women's heroic story actually is closely associated with a repressed situation that forced them to give some contributions. Their strategy to against colonialism is subversive toward power relations which stand on Islamic interpretation that promotes gender inequality.

\section{ACKNOWLEDGMENTS}

Thank you to Ms. SitiMalikhahTowaf for providing ideas and corrections on gender history in Indonesia. Also official of LP2M, History Departement, Faculty of Social Science, UniversitasNegeriMalang for the guidance and support of this research.

\section{REFERENCES}

[1] Yuliati, Khakim, M. N. L., \& Towaf, S. M. (2019). KARTINI'S CONTRIBUTION IN DEVELOPING THE ART OF CARVING MACAN KURUNG. In Sukamto, S. Susilo, A. Sapto, \& J. Sayono (Eds.), Proceedings of the 1st International Conference on Social Knowledge Sciences and Education (ICSKSE 2018). 320, pp. 141-
143). DOI: https://doi.org/https://dx.doi. org/10.2991/icskse-18.2019.27

[2] Khakim, M. N. L. (2018). KESADARAN SEJARAH DALAM NOVEL 'MENUNGGU BEDUK BERBUNYI' HAMKA ( 1950 ) SEBAGAI PENGEMBANGAN MATERI AJAR SEJARAH INDONESIA MODERN. 1(2), pp. 163-175. DOI: https://doi.org /http://dx.doi.org/10.17977/um033v1i22018 p163

[3] Zed, Mestika. (2009). Metode Penelitian Kepustakaan. Jakarta: Yayasan Obor Indonesia.

[4] Hamid, Abd Rahman \& Madjid, Muhammad Saleh. (2011). Pengantar Ilmu Sejarah. Yogyakarta: Ombak.

[5] Reid, Anthony. (2005). Asal-usul Konflik Aceh. Jakarta: Yayasan Obor Indonesia.

[6] Wahyuningroem, Sri Lestari. (2005). Jurnal Antropologi Indonesia,29(1),pp. 93101.

[7] West, Lois A. (1997). Feminist Nationalism. New York-London: Routledge.

[8] Enloe, Cynthia. (1990). Bananas Beaches E Bases, Making Feminist Sense of InternationalPolitics. Berkeley Los Angeles: University of California Press.

[9] McClintock, Anne. (1993). Feminist Review, 44,pp. 61-62.

[10] Mernisi, Fatima. (1991). Women and Islam: A Historical and Theological Enquiry. Oxford:Basil Blackwell.

[11] Moghissi, Haideh. (1999). Feminism and Islamic Fundamentalism. London and New York:Zed Books.

[12] Kamajaya. (1981). Lima Putera-Puteri Aceh Pahlawan Nasional. Yogyakarta: U. P. Indonesia.

[13] Veer, P. van. (1985). Perang Aceh: Kisah Kegagalan Snouck Hurgronje. Jakarta: Grafiti Pers.

[14] Ahmad, Z., Sufi, R., Ibrahim, M., \& Sulaiman, N. (1982). Sejarah Perlawanan Terhadap Imperialisme dan Kolonialisme di Daerah Istimewa Aceh (p. 82-109). Jakarta: 
Departemen Pendidikan dan Kebudayaan.

[15] Azwar, P. H. (2011). Perempuan Bercahaya dalam Lintasan Sejarah Aceh. Jakarta: Yayasan Tun Sri Lanang.

[16] Chirzin, Muhammad, et al. (2017). Reformulasi Ajaran Islam: Jihad, Khilafah, dan Terorisme. Bandung: PT Mizan Pustaka.

[17] Hasjmy, A. (1993). Wanita Aceh dalam Pemerintahan dan Peperangan. Banda Aceh: CV Gua Hira'.

[18] Talsya, T. A. (1982). Cut Nyak Meutia: Srikandi yang Gugur di Medan Perang Aceh. Jakarta: Mutiara.

[19] Said, H. M. (1985). Aceh Sepanjang Masa. Medan: PT. Harian Waspada Medan.
[20] Hardi, S. H. (1993). Daerah Istimewa Aceh: Latar Belakang Politik dan Masa Depannya. Jakarta: PT Karya Unipress.

[21] Jakobi, Tgk. A. K. (1998). Aceh dalam Perang Mempertahankan Proklamasi Kemerdekaan1945-1949 dan Peranan Teuku Hamid Azwar sebagai Pejuang. Jakarta: PTGramedia Pustaka Utama.

[22] Madjid, M. Dien. (2013). Catatan Pinggir Sejarah Aceh. Jakarta: Yayasan Pustaka Obor Indonesia.

[23] Ali, Fachry, et all. (1999). Regionalisme, Nasionalisme, dan Ketahanan Nasional. Yogyakarta: GajahMada University Press.

[24] Wieringa, Saskia. (1995). Subversive Women: Historical Experiences of Gender and Resistance. London and New Jersey: Zad Book Ltd. 